\title{
Pojęcie negacji i niczego w poznaniu ludzkim*
}

Niejedna rzecz, która na pierwszy rzut oka wydaje się nam mało ważna, drobna, jasna pod każdym względem, okazuje się kwestią niezwykłej wagi, kiedy zwrócimy na nią należytą uwagę i jej granice znikną nam z duchowych oczu i pogrążą się w tajemniczej ciemności.

Z czymś podobnym mielibyśmy do czynienia, gdybyśmy chcieli zbadać genezę i znaczenie pojęcia negacji.

Pojęcie negacji jest - wraz z pojęciem asercji (jest, być) - zasadniczym pojęciem naszego poznania. Dlatego właśnie jest ono znane każdemu człowiekowi, który coś myśli i o czymś sądzi. Słowa nie i nic - rozumie każdy człowiek. Cóż może być wszak jaśniejszego i bardziej zrozumiałego od asercji i negacji: od słów być - nie być, jest - nie ma, tak (owszem) - nie, coś - nic? Jednakże jasność ta występuje jedynie wtedy, kiedy obracamy się w zwykłych granicach naszego życia. Kiedy zwrócimy się do filzoficznego znaczenia negacji i niczego, jasność zaczyna znikać: pojęcie niczego okazuje się mętne.

Przekonamy się, że rzeczywiście tak jest, kiedy prześledzimy historię filozofii. Filozofowie stosunkowo mało uwagi poświęcali samemu POJ̨̨CIU negacji; cześciej zajmowali się oni tym, co pojęciu negacji i niczego odpowiada

* Oryginał: Dr. Gavriïl Kostel'nik, Ponâttâ negaciï ì nì̌ogo v lûds'kim piznìnnì, [w:] Al'manah ukraïns'kih bogosloviv (Almanach teologów ukrainskich), Lwów 1914, s. 27-42 (przyp. tłum.). Publikacja została zrealizowana przy wsparciu Fundacji na Rzecz Nauki Polskiej w ramach programu dla młodych naukowców „Start”. 
w rzeczywistości (tzn. w świecie realnym). Właśnie na tym gruncie pojawiają się dziwne - nieraz niezgodne ze zwykłym pojmowaniem tego słowa - pojęcia „niczego” u różnych filozofów. Jest tak dlatego, że rzeczywiście mamy tutaj do czynienia z poważnymi trudnościami. W świecie realnym zachodzą ciągłe zmiany: to, co było, znika; powstaje to, czego nie było. Nasuwają się $\mathrm{w}$ związku z tym różne pytania. W jaki sposób jakaś rzecz może Powstać? Czy w świecie zachodzą tylko zMIANY POŁĄCzeŃ niezniszczalnych elementów (atomów)? Czy coś powstaje z NICZEGo? Ale w jaki sposób coś może powstać z niczego? Jaki jest stosunek "niczego" poprzedzającego rzecz, która powstaje, do tej samej rzeczy już zrealizowanej? Jaki jest w ogóle stosunek "niczego" do rzeczywistości? Czy w początkach rzeczywistości „nic” i „byt” (das reine Sein i reines Nichts u Hegla) nie różnią się od siebie? Czy w nieskończoności (w absolucie, w Bogu) nic jest tożsame z bytem?

Te i podobne pytania dręczyły i dręczą filozofów. Nie zamierzam ich rozstrygać: nie zamierzam szczegółowo badać onTOLOGICZNEGO „nic” (tzn. tego, co w realnym świecie odpowiada pojęciu niczego), lecz chciałbym jedynie zwrócić uwagę na samo POJĘCIE negacji (tzn. na LOGICZNO-PSYCHOLOGICZNE znaczenie negacji). Zajmę się więc następującymi pytaniami. Jaką korzyść przynosi pojęcie negacji naszemu poznaniu? Jakie są funkcje negacji w poznaniu ludzkim? Jakie są odmiany pojęcia negacji? W jaki sposób dochodzimy do pojęcia negacji itd.? Zanim się jednak do tego zabierzemy, powinniśmy się chociaż pobieżnie zapoznać z różnymi poglądami filozofów dotyczących pojęcia niczego, mimo że te poglądy, jak zauważyliśmy, w większości tyczą się ontologicznego pojęcia "niczego". Jest to potrzebne do tego, aby interesujący nas temat wszechstronnie naświetlić.

\section{II}

Fredegis (Fredegisus, IX w. n.e.), uczeń Alkuina, jest autorem pracy „De nihilo et tenebris” („O niczym i ciemnościach”), w której usiłuje dowieść, że „nic i ciemność” nie jest czystą negacją wszelkiego bytu, lecz czymś realnym, z czego Bóg stworzył świat. Odwrotnie stawiał sprawę Jan Szkot Eriugena (Scotus Eriugena), który w tym samym stuleciu twierdził, że Bóg sam w sobie jest NICZYM; kiedy więc Pismo Święte mówi, że Bóg stworzył świat z niczego, to należy to rozumieć w taki sposób, że Bóg wyprowadził (stworzył) świat $\mathrm{z}$ samego siebie.

Te dwa skrajne stanowiska możnaby sformułować w sposób następujący: 
(1) Podstawą wszelkiego bytu jest zawsze coś realnego; z niczego nic nie może powstać.

(2) W początkach bytu nic i coś (bycie) są sobie równoważne; cała rzeczywistość pierwotnie wypływa $\mathrm{z}$ niczego.

Przy pierwszym twierdzeniu najbardziej konsekwentnie obstawała w starożytności szkoła eleacka (Parmenides), a za drugim dopiero w zeszłym wieku opowiedział się Hegel († 1831), który za punkt wyjścia swojej filozofii przyjął początkową tożsamość bytu i niebytu:

Byt, nieokreślona bezpośredniość jest faktycznie Niczym i niczym więcej ani niczym mniej niż Nic. [...] Nic, czyste Nic. [...] Czysty byt i czyste Nic są więc jednym i tym samym ${ }^{1}$.

Neoplatonicy (III w. n.e.) najwyraźniej jako pierwsi dali asumpt do pojmowania absolutu (Boga) jako „nie-czegoś” (Nichtetwas) - niczego. Polegało to na tym, że zaczęli oni z wielką przesadą odmawiać Bogu wszelkich cech przedmiotów skończonych: według nich Bóg nie był ani tym, ani owym; nie był taki ani owaki. Nic więc dziwnego, że w końcu doszli do odmówienia Bogu nawet cechy bycia. Tendencja obecna u neoplatoników rozwinęła się u Pseudo-Dionizego Areopagity (theologia negativa), a sięgnęła szczytu, jak już powiedziano, u Szkota Eriugeny. Żydowska kabała (w księdze Jezirach) również określa Boga jako „Nichtetwas” (ain soph). Kardynał Mikołaj z Kuzy (Cusanus, $\dagger 1464) \mathrm{w}$ swoich głębokich rozważaniach dochodzi do pojmowania Boga jako „nie-czegos"” (coincidentia oppositorum in absoluto). Mistyk Jakub Böhme († 1642) pisze, że Bóg jest „ein ewiges Nichts”.

Dwa skrajne pojmowania „niczego”, które przytoczyliśmy, są zbieżne w tym punkcie, że według jednego i drugiego „nic” (ontologiczne) jest właściwie jakimś realnym substratem bytu, z tym że w pierwszym wypadku stoi się na stanowisku REALNOŚCI tego substratu, a w drugim - jego NIEOKREŚLONOŚci (nie-coś). Jasno widać to w wypowiedzi Hegla: „Byt i niebyt są jednym i tym samym". [...] W twierdzeniu mowa jest o czystych abstrakcjach bytu i niebytu, a zastosowanie czyni z nich określony byt i określone Nic. O określonym bycie zaś nie ma tu [...] mowy. ${ }^{2}$

${ }^{1}$ K. Werder, Logik als Kommentar u. Ergänzung zu Hegels Wissenschaft der Logik, Berlin 1841. Tutaj i niżej odpowiedni fragment jest cytowany bezpośrednio z Nauki logiki, przeł. A. Landman, t. 1, Warszawa 1967, s. 92-93 (przyp. tłum.).

${ }^{2}$ L.c. 
Zgodnie z drugim przytoczonym przez nas twierdzeniem, „nic” - jako substrat bytu - nie znajduje się w ograniczonych, konkretnych rzeczach, lecz tylko w samych POCZĄTKACH bytu. Jest jeszcze jedno rozumienie niczego, według którego nic (ontologiczne) jest zupełnie usunięte $\mathrm{z}$ absolutu, natomiast odgrywa pewną rolę w ograniczonych, zmiennych rzeczach. Tę myśl najwyraźniej sformułował Tomasz Campanella († 1639), głosząc, że każda rzecz ograniczona składa się z bytu i NIEBYTU (z ograniczonego bytu i nieograniczonego niebytu); i akurat niebyt jest przyczyną ograniczoności rzeczy. Coś podobnego twierdził już Demokryt (V w. p.n.e.); uważał on, że każda rzecz składa się z pełni ( $\pi \lambda \hat{n} \rho \varepsilon \varsigma)$ i próżni ( $\chi \varepsilon v o ́ v)$; ów pierwiastek próżny Demokryt określa jako niebyt ( $\mu$ j́ óv). Analogiczne poglądy można znaleźć także u Barucha Spinozy ( $† 1677)$. Wynika z nich, że każda rzecz jest ograniczona o tyle, o ile nie ma udziału w absolucie (determinatio est negatio).

Trudną kwestię ograniczoności i powstawania rzeczy rozstrzygnął Arysto-

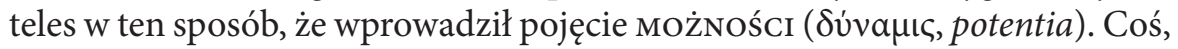
czego jeszcze nie ma, a może być, jest w możności; to, co nie posiada całej pełni bytu, jest jednak w możności przyjąć pewien stopień realności. Możność nie jest „niczym”, ale nie jest też i w pełni zrealizowaną rzeczywistością.

Trzeba powiedzieć wyraźnie, że pojęcie możności nie wyjaśnia w zadowalającym stopniu powstawania rzeczy; omija ono tylko chytrze pierwsze stadium owego powstawania i od razu zwraca uwagę na drugie stadium tj. stadium, w którym rzecz już jest "gotowa” do tego, żeby powstać (nie ma potrzeby tutaj tej myśli szerzej rozwijać). A jednak Arystoteles zrobił słusznie, kiedy pojęcie ontologicznego nic - jako jakiegoś współczynnika (u Demokryta) lub przeszkody (u eleatów) w powstawaniu rzeczy - w ogóle pominął i zastąpił je pojęciem możności. Było to słuszne dlatego, że w rzeczywistości nie ma żadnego "niczego", lecz jest tylko to, co jest; każda rzecz jest tym, czym jest, swoją realnością, a nie jakimś niebytem - negacją. Wiele racji ma Trendelenburg, mówiąc: „Czysta negacja nie znajduje się nigdzie poza myślą. Dlatego jest nadużyciem podnosić czystą negację do roli jakiegoś realnego samodzielnego czynnika realnego, jak gdyby niebyt (das Nicht-Sein) działał w taki sam sposób jak i byt (das Sein)"3.

W ten sposób doszliśmy do naszego zasadniczego tematu, w ramach którego negację i nic traktować będziemy jako czyste pojęcia - tj. jako czynniki

\footnotetext{
${ }^{3}$ Ad. Trendelenburg, Logische Untersuchungen, Die Verneinung (XII), t. 2, Leipzig 1862.
} 
w idealnym świecie naszego umysłu ${ }^{4}$, a nie jako coś istniejącego w realnym świecie.

Cała ważność negacji i jej różnych odcieni leży w naszych myślach, a nie w świecie rzeczywistym. Mówienie o jakimś określonym niczym, które miałoby się znajdować w rzeczywistym świecie, nie ma żadnego sensu. Nic ontologiczne nie ma żadnego określenia. Nic logiczne oznacza właśnie ów brak wszelkich określeń w realnym świecie. Tylko byt posiada określenia.

Byt jest osıą, wokół której krążą wszystkie nasze myśli i bez której wszelkie myśli tracą swoje znaczenie. Całkiem słusznie zauważył Karol Bovillus (Bouillé, † 1553), że „niczego” nie możemy pomyśleć bez „czegoś” (bytu).

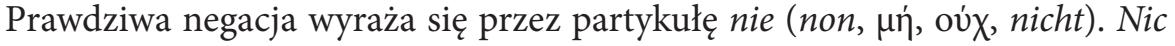
jest złożone z partykuły nie i słowa coś. Podobnie jest w języku łacińskim, greckim, niemieckim itd. Ciekawa pod tym względem jest rozprawa Hipolita Cegielskiego De negatione (Berolini 1840). Autor bada w niej negację z GRAMATYCZNEGo punktu widzenia. Widać, że nie jest wyrażeniem synkategorematycznym - tj. takim słowem, które tylko w połączeniu z innym (kategorematycznym) słowem otrzymuje PEŁNE znaczenie (np. nie chodź!, niemiły, nieskończony, nic itd.). Trafnie zauważa Cegielski, że „negacja nie jest żadną negacją, JEŻELI NIE JEST NEGACJĄ JAKIEJŚ RZECZY"5.

Wspomniany Bovillus (autor rozprawy „De nihilo“) uważa pojęcie „niczego" za bardzo pożytecztne właśnie dlatego, że „nic“ nie możemy pomyśleć bez bytu: stąd Bovillus za pomocą pojęcia „niczego" chce wykazać realność świata zewnętrznego i istnienie Boga. Nie będę wchodzić w dyskusję, czy Bovillus ma rację, czy nie ma, ale jedno jest pewne, że bez pojęcia negacji nie bylibyśmy w stanie nieczego udowodnić. Nie chodzi oczywiście o to, że nie bylibyśmy w stanie czegokolwiek poznać, spostrzec - percypować. Chodzi o niemożliowść udowodnienia czegokolwiek - a to jest zupełnie inna sprawa. Do przeprowadzenia każdego dowodu konieczne są: (1) wstępne pojęcia, takie jak wątpienie i pytanie; (2) zasady (w szczególności zasada sprzeczności), na których musimy się oprzeć w pocesie samego dowodzenia; (3) poczucie KONIECZNośCI dowodzonego sądu i NIEMOŻLıwoścI (przynajmniej tymcza-

\footnotetext{
${ }^{4} \mathrm{~W}$ oryginale używany jest wszędzie termin „duh”, który konsekwentnie oddajemy za pomocą lepiej brzmiącego po polsku słowa „umysł” (przyp. tłum.).

${ }^{5}$ L.c., s. 24.
} 
sowej) sądu przeciwnego, będące wynikiem dowodu. Wszystko to wymaga pojęcia negacji, i tylko przy jej użyciu, dowód jest możliwy.

W umyśle ludzkim, jako podmiocie POzNANIA, należy rozróżnić dwie sfery. Przede wszystkim - w dzieciństwie - poznajemy rzeczy konkretne: zmysłowe, indywidualne. W tym okresie obracamy się w sferze WYOBRAżEŃ ZMYsŁowych. Czyste pojęcia, takie jak prawo, prawda, przyszłość, sposób, byt itd., jeszcze nie są nam znane. Z czasem niezauważalnie wkraczamy w sferę CZYSTYCH POJĘĆ, tj. uzyskujemy pojęcia, którym w zmysłowym świecie nie odpowiada żadna konkretna lub w ogóle żadna rzecz. CzYsTe POJĘCIA WZNOSZĄ SIĘ POZA GRANICE, W KTÓRYCH MIEŚCI SIĘ ŚWIAT RZECZYWISTY, i stają się potężnym środkiem, za pomocą którego umysł jest w stanie nieskończoną liczbę konkretnych rzeczy i możliwości zredukować Do JEDNEGO wyrazu lub odszukać takie cechy rzeczy czy same rzeczy, które odgrywają bardzo ważną rolę w świecie rzeczywistym, a poprzez zmysły nie mogą nam się zamanifestować. Weźmy dla przykładu słowo możliwość. Pojęciu możliwości nie odpowiada żadna konkretna rzecz; „możliwością” nie jest ani kamień, ani gwiazda, ani przestrzeń, ani nic do nich podobnego. Mimo tego jednak pojęciu możliwości w rzeczywistym świecie coś odpowiada - coś, co jest obecne we wszystkich przejawach bytu, my zaś sprowadzamy to coś do jednej istoty LOGICZNEJ (do jednego wyrazu) i w ten sposób opanowujemy niewidzialne wymiary i nieskończoną różnorodność bytu. Na podstawie tego, co zostało powiedziane, staje się jasne, że czyste pojęcia dostosowują się nie tyle do granic, w których mieści się świat rzeczywisty, ile do naszych własnych potrzeb: tak, abyśmy mogli za pomocą Rozumu opanować nieskończoną różnorodność bytu. Właśnie dlatego stwarzamy nieraz takie pojęcia, które są nawet PRZECIWIEŃSTWEM wszystkiego tego, co znajduje się $\mathrm{w}$ świecie rzeczywistym. Jednym $\mathrm{z}$ takich POMOCNICZYCH pojęć, niewątpliwie najbardziej pożytecznym i najbardziej odległym od przedmiotów świata rzeczywistego, jest pojęcie negacji i niczego. Wiadomo, jakie doniosłe funkcje spełnia zero w matematyce. Chociaż samo ono nie jest żadną liczbą, w pewien sposób uzależnia liczby od siebie - co jest bardzo praktyczne, gdy chcemy łatwo opanować liczby w ich różnych konfiguracjach (np. 0,1, 100 itd.) - oraz uzupełnia niektóre funkcje liczb (np. 2 - 2 $=0$ ). Wiadomo, że zera długo nie było w matematyce (Grecy i Rzymianie nie mieli znaku dla zera; zero w ich notacji liczb nie spełniało żadnych funkcji). Jakże można bowiem było wprowadzać między liczby to, co nie jest liczbą?

Sama natura naszego umysłu rozwiązała jednak już bardzo dawno temu ten problem: między ogniwa bytu wprowadziła ona pojęcie niczego, żEBY WŁAŚNIE W TEN SPOSÓB ŁATWIEJ OPANOWAĆ SAM BYT. 
Pojęcie negacji staje się dla umysłu ludzkiego jak gdyby ostrym nożem, rozcinającym określenia, odnoszące się do rzeczy świata realnego lub wyobrażonego. Spostrzegamy np. jakiś kamień, który ma pewną wielkość. Śledząc oczyma szerokość tego kamienia, dochodzimy do granicy, w której kamień się kończy; kiedy wzrokiem przesuwamy się jeszcze dalej (poza granice kamienia), spontanicznie nasuwa się nam pojęcie negacji: dalej kamień nie sięga. W ten sposób granice kamienia poznaliśmy PoDwójNIE, tj. pozytywnie (dotąd kamień sięga) i negatywnie (dalej kamień nie sięga). Jest zrozumiałe samo przez się, że takie podwójne poznanie jakiegoś przedmiotu o wiele przewyższa pojedyncze (tylko pozytywne) percypowanie przedmiotu. Kiedy np. podwójnie (tzn. pozytywnie i negatywnie) poznam jakąś prawdę (np. że $2+2$ jest 4 , i i że $2+2$ nie jest nie 4 ), to $z$ tego poznania rodzi się POJĘCIE KonieCZności (że $2+2$ MUsi być 4 ). Stąd takie podwójne poznanie wywołuje w naszym umyśle NIEPODWAŻalną PEWNość. Gdybyśmy nie byli wyposażeni w pojęcie negacji, nie moglibyśmy mieć o żadnej rzeczy wyższej (metafizycznej) pewności; mielibyśmy tylko - że tak powiem - pewność MECHANICZNĄ. Mechanizm, który zachodzi między podmiotem, który poznaje i bywa dotknięty, a przedmiotem, który oddziaływuje na podmiot, wymagałby od nas uznania (assensus) rzeczywistości swojego działania. W taką mechaniczną pewność są wyposażone zwierzęta.

Ale i przeciwnie: gdyby nasze myślenie nie zawierało w sobie pojęcia negacji, nie moglibyśmy o żadnej rzeczy wątpić, żadnemu zjawisku NIE DAĆ WIARY. W tym wypadku bylibyśmy zmuszeni uznawać wszystko, co by się nam manifestowało; nie bylibyśmy w stanie pomyśleć: to NIE JEST TAK; możliwe, że to nie jest tak, jak się nam manifestuje. Kiedy np. widzimy słońce tak, jak ono się nam ukazuje, możemy pomyśleć, że słońce nie jest takie małe, jak nam się przedstawia. Na odwrót: zwierzęta nie są w stanie tego sobie pomyśleć; dla nich słońce pozostanie zawsze takim, jak im się przedstawia. Tymczasem rodzaj ludzki przede wszystkim dlatego, że może wątpić, że może nie dawać czemuś wiary - a więc dlatego, że jest wyposażony w pojęcie negacji - potrafił dojść do poznania prawdziwej wielkości słońca. Staje się więc jasne, że umysł ludzki za pomocą pojęcia czystej negacji uwalNia sIĘ (pod pewnym względem) od mechanizmu zlokalizowanego między podmiotem, w którym rodzi się poznanie, i przedmiotem, który inicjuje to poznanie w podmiocie. Wspomniany mechanizm mówi mi, że słońce jest małe; ja jednak mogę, jak to już zostało powiedziane, nie dać temu wiary.

W ten sposób pojęcie negacji służy nam właśnie do tego, abyśmy mogli poznać jasno i pewnie RZECZYwiste OKREŚLENIA bytu. Podobnie jak w ma- 
tematyce (w arabskiej notacji liczb) zero nadaje właściwe znacznie liczbom, a w malarstwie cień podnosi właściwą siłę różnych barw, tak też w poznaniu pojęcie negacji daje rzeczywistym rzeczom ich właściwą RZECZYwIsTość (chodzi o rzeczywistość Poznaną, a nie aktualną). Podobnie jak zero w matematyce zmienia wartość różnych liczb (np. 0,10, 2000 itd.) - pojęcie negacji w poznaniu ludzkim zmienia wartość różnych pojęć i w ten sposób WZBOGACA nasz POZNANY (nie rzeczywisty!) świat i ułatwia orientację w tym poznanym świecie. Jest mnóstwo słów skonstruowanych w ten sposób, że do jakiegoś słowa dodajemy negację, i tym samym otrzymujemy nowe znaczenie (pojęcie); np. niemało, nieskończony, niepodzielny, niewola itd. Spośród tych pojęć szczególnie ważne dla nas są te, za pomocą których wykraczamy poza granice rzeczywistego świata materialnego (jak np. nieskończoność, nieśmiertelność, niezmienność itd.), ponieważ dzięki nim zbliżamy się do absolutu: stajemy się jak gdyby „bogami”. Głęboka jest myśl Arystotelesa, że dusza ludzka poznając różne przedmioty w tajemniczy sposób staje się pod pewnym względem wszystkim (każdym przedmiotem), co poznaje. Otóż poznając cechy absolutne (Boga), stajemy się do Niego podobni.

Pojęcia nieśmiertelności, nieskończoności itd. w rzeczywistości nie są pojęciami negatywnymi, lecz pozytywnymi. W ten sposób znów potwierdza się nasz wniosek, że pojęcie negacji służy właśnie do tego, żebyśmy mogli łatwiej opanować (rozumem) rzeczywistość bytu.

Niezwykłą rolę odgrywa pojęcie negacji w rozumowaniu (ratiocinatio). Szczegółowe zbadanie tej roli negacji jest prawie niemożliwe. Wystarczy przypomnieć, że zasada sprzeczności, która jest niewątpliwie zasadą negacji ${ }^{6}$, stanowi niezbędny element w każdym akcie sądzenia (iudicium), w każdym rozumowaniu (które nie jest niczym innym jak tylko REFLEKSYJNYM formułowaniem sądu). Tak więc pojęcie negacji jest osnową wszystkich procesów naszego poznania i w każdym z nich odgrywa rolę twardego fundamentu, na którym opiera się nasz umysł.

Poznawszy wagę negacji w poznaniu ludzkim, jesteśmy w stanie odsłonić SKALĘ POJĘĆ POMOCNICZYCH, które umożliwiają nam opanowanie nieskończonej różnorodności bytu. Stają tutaj naprzeciw siebie jak gdyby dwa bieguny: twierdzenie i przeczenie, być (w znaczeniu czysto logicznym, a nie ontologicznym) i nie-być. Między tymi dwoma biegunami środek zajmuje pojęcie PYTANIA. W pytaniu twierdzenie i przeczenie schodzą się ze sobą. Każde pytanie dąży do zbliżenia się z twierdzeniem lub z przeczeniem. Czy

\footnotetext{
${ }^{6}$ Por. moją rozprawę De principiis cognitionis fundamentalibus (w druku).
} 
należy dany predykat podmiotowi przypisać? Czy zaprzeczyć? Czy jest? Czy nie jest? (np. Czy słońce jest wielkie? Czy nie jest wiekie?). Mejsce między pytaniem a negacją zajmuje $z$ kolei WĄTPIENIE (por. wydaje się, że słońce nie jest wielkie); między twierdzeniem a pytaniem stoi zaś PRZYPUSZCZENIE (opinio) (por. wydaje się, jest możliwe, iż słońce jest wielkie). Tak więc cała skala [postaw] przedstawia się w sposób następujący: (1) twierdzenie (positio), (2) przypuszczenie (opinio), (3) pytanie (interrogatio), (4) wątpienie (dubium) i (5) przeczenie (negatio).

Gdybyśmy nie mieli pojęcia pytania, nie moglibyśmy żadnego problemu zbadać NAUKOwo po prostu dlatego, że brak byłoby samej inicjatywy do takiego badania. Gdybyśmy nie mieli pojęcia negacji, nie byłaby nam znana cała skala pojęć pomocniczych. Jak bowiem bez pojęcia negacji można byłoby zrozumieć pytanie? Jak wątpić (skoro za pomocą wątpienia zbliżamy się do przeczenia)? Jak coś przypuszczać (skoro za pomocą przypuszczenia zbliżamy się do twierdzenia - ale nie wykluczamy przeczenia)? Znowu więc przekonujemy się, że gdybyśmy nie byli wyposażeni w pojęcie negacji, to z całej wspomnianej skali pozostałoby nam tylko twierdzenie (positio) - ale i to nie refleksyjne (pośrednie), lecz tylko prymitywne (bezpośrednie). W takim wypadku pytanie, wątpienie i przypuszczenie byłyby pozbawione odniesienia do negacji, a bez tego nie miałyby żadnego znaczenia.

Skala pojęć pomocniczych rzuca światło na pewną część MECHANIZMu naszego myślenia. Logicy nie poświęcali wystarczającej uwagi pytaniu i negacji (w tym znaczeniu, które tutaj przedstawiliśmy); dlatego rzadko który system logiki formalnej ${ }^{7}$ ujawnia sam mechanizm logiki naturalnej; przeważnie rekonstruują one tylko jej NIEKTÓRE FRAGMENTY. A przecież zadaniem logiki formalnej (naukowej) jest właśnie odkrycie całego mechanizmu logiki naturalnej. Mając na uwadze skalę pojęć pomocniczych i to, co z tej skali samo przez się wypływa, można by w pewnym stopniu przybliżyć logikę formalną do logiki naturalnej ( $\mathrm{tj}$. można by odpowiednie fragmenty logiki formalnej połączyć w organiczną całość).

\section{IV}

Pojęcie negacji w gruncie rzeczy jest tylko jedno (wyraża się ono słowem nie). Różne odcienie negacji mają źródło nie w samem pojęciu negacji, lecz $\mathrm{w}$ różnych połączeniach tego pojęcia z innymi pojęciami. Powiedzieliśmy już,

${ }^{7}$ Tu i niżej w oryginale: „logìka štučna” (przyp. tłum.). 
że słowo nie jest synkategorematem, i w załeżności od tego, z jakim słowem się łączy, nabiera różnych odcieni. Ważne jest przede wszystkim połączenie negacji z pojęciem nieokreślonej pozycji (ze słowem coś). W ten sposób otrzymujemy rzeczownik negatywny: nic. Pojęcie „niczego" jest czystym pojęciem; natura naszego umysłu jest jednak taka, że chciałaby ona wszystkie czyste pojęcia jeżeli nie zmienić, to przynajmniej połączyć z jakąś zmysłową rzeczą; dlatego często przedstawiamy sobie "nic” jako jakąś PRóŻniĘ, lub cIEMNość. Takie uzmysłowione pojęcie "niczego" jest relatywne, ponieważ w rzeczywistości próżnia i ciemność nie są czymś absolutnym. O ile jednak w próżni (pustej przestrzeni) nie znajdujemy rzeczy (czegoś zmysłowo pozytywnego), o tyle ta [pusta] przestrzeń wydaje się nam „niczym” (tj. brakiem zmysłowo pozytywnych rzeczy). Podobnie ciemność w porównaniu z jasnością (światłem), w której unaoczniają się nam zmysłowo pozytywne byty, wydaje się nam „niczym”.

Jeszcze wyraźniej zaznacza się natura relatywnego nic w innych przypadkach. Oto np. myślałem, że znalazłem monetę, a okazało się, że to jest jakieś szkiełko; kiedy mnie ktoś w tej chwili zapyta: Co znalazłeś? - odpowiem: Nic! Szkiełko, które znalazłem, nie jest w rzeczywistości „niczym”, ale jest ono niczym z TEGO, co zamierzałem znaleźć.

Jest pewna różnica między pierwszym a drugim relatywnym „niczym”. W pierwszym "nic” nasze zMYSŁY nie znajdują żadnego bytu pozytywnego; w drugim - zmysły znajdują pewną rzecz (szkiełko), ale nasza MYśL nie znajduje tego, czego się spodziewała.

Nic absolutne - to jest brak wszelkiego bytu (bez żadnego odniesienia do naszych zmysłów czy myśli).

Kant rozróżnia cztery odcienie niczego ${ }^{8}$ : (1) „puste pojęcie (leerer Begriff) bez przedmiotu (ens rationis) - np. pojęciu „wszystkiego” nie odpowiada żadna rzecz, więc jest ono tylko ens rationis (istnieniem w wyobrażeniu); (2) pusty przedmiot (leerer Gegenstand) jakiegoś pojęcia (nihil privatimum), tj. brak przedmiotu tam, gdzie on powinien być - np. ślepota, cień itd.; (3) puste spostrzeganie (leere Anschauung) bez przedmiotu - np. czas, przestrzeń (według teorii Kanta); (4) pusty przedmiot (leerer Gegenstand) bez pojęcia, tj. właściwe nic - coś sprzeczne, absolutnie niemożliwe. Jeżeli przypatrzeć się tym odcieniom niczego, o których mówi Kant, to widać, że nie analizuje on odcieni pojęcia „niczego", lecz tylko samo nic ontologiczne w JEGO RELACJI DO NASZYCH POJĘĆ. Należy podkreślić, że Kant pojmuje naturę naszych po-

${ }^{8}$ Krit. d. rein. ver. Elemlehre: II. Teil, I. Abt. II. Buch (I. Ausgabe). 
jęć swoiście - w sposób, który zupełnie nie odpowiada rzeczywistości. Tymczasem pojęciu „wszystkiego” (pierwszy odcień niczego u Kanta) oraz czasu i przestrzeni (trzeci odcień niczego u Kanta) w świecie rzeczywistym coś odpowiada, aczkolwiek to „Coś” NIE JEST JEDNĄ - INDYWIDUALNĄ RZECZĄ. O naturze czystych pojęć już wspomnieliśmy, więc nie ma potrzeby, żeby przy tej okazji to powtarzać.

Przeczyć można na dwa sposoby: (1) bez wyraźnego pojęcia negacji, tj. nie używając słowa "nie”; (2) z wyraźnym pojęciem negacji. O tym ostatnim sposobie nie ma potrzeby więcej mówić. Natomiast pierwszego sposobu przeczenia używamy dość często, przede wszytkim przy przeciwstawianiu sobie jednych rzeczy innym (np. czarny - biały, wielki - mały, dobry - zły itd.). Kiedy mówię jest biały, to tym samym przeczę temu, że jest czarny, ale bez wyraźnego pojęcia negacji. Jednakże każde takie przeczenie możemy wyrazić $\mathrm{w}$ formie wyraźnej negacji, np. jest czarny = nie jest biały, a jest czarny. Przeczenie bez wyraźnej negacji jest PROCESEM PODWójNYM: w nim nie tylko negujemy pewną rzecz (nie jest biały), lecz zarazem sTWIERDZAMy inną rzecz (jest czarny). W tej podwójnej czynności naszego umysłu przeważa pozycja, gdyż negacja jest zrozumiała sama przez się.

Każda rzecz chociażby częściowo wyklucza inną rzecz (gdyby tak nie było, to nie mogłoby być dwóch rzeczy, lecz tylko jedna); dlatego stwierdzając jedną rzecz, tym samym wykluczamy inne. Gdzie jednak coś wykluczamy, tam przeczymy - negujemy. Tak np. spać - chodzić, drzewo - kamień itd. wykluczają się wzajemnie. Trafiają się więc i takie przeczenia: N. twierdzi: Piotr śpi. X. przeczy: Piotr chodzi. Tutaj też mamy do czynienia z tą podwójną czynnością umysłową, o której mowa była wyżej. Przeczenie Piotr chodzi można wyrazić w sposób następujący: Piotr NIE śpi, a chodzi.

W pewnych językach są słowa, które są GRAMATYCZNIE POZYTYWNE, A LOGICZNIE NEGATYWNE. W języku polskim brakować, brak, brakuje - są równoważne wyrazowi nie $m a^{9}$. Na odwrót: są słowa GRAMATYCZNIE NEGATYWNE, a LOGICZNIE POZYTYWNE - np. nieskończony, niemało itd. Bywa tak wtedy, kiedy negujemy pojęcie niedoskonałości (ograniczoności, małości itd.). Najniedoskonalsze w obrębie bytu jest nic, i właśnie jego negacja jest prototypem wszystkich gramatycznych negacji i logicznych pozycji. Negacja negacji daje pozycję. Na przykład: nie nic = coś; nie niezły = zły; nie brak jest $=$ jest itd.

${ }^{9} \mathrm{~W}$ oryginale chodzi odpowiednio o słowa ukraińskie: бракувати, брак, бракує і нема (przyp. tłum.). 
Negacja obejmuje sobą cały zakres pojęcia (extensio), do którego się dołącza, lecz nie obejmuje sobą całej treści tego pojęcia (comprehensio). Należy tutaj zaznaczyć, że negacja nie obejmuje sobą wszystkich cech (notae), które tworzą jakieś pojęcie, do którego negacja się dołącza, KIEDY TE CECHY BIERZEMY ODDZIELNIE (separatim); kiedy jednak wszystkie cechy bierzemy razem, to negacja obejmuje sobą tę CA£ość jako taką. Mam np. przed sobą kwadrat i mówię: To nie jest trójkąt. W ten sposób wykluczam z kwadratu wszystkie możliwe trójkąty, a więc wykluczam wszystkie cechy, które tworzą trójkąt, RAZEM WZIĘTE; nie wykluczam natomiast wszystkich tych cech wziętych oddzielnie: mianowicie nie wykluczam linii, kątów itd., gdyż cechy te posiada też kwadrat. Kiedy jednak w jakimś pojęciu nie jesteśmy w stanie WYRÓŻNIĆ WIĘCEJ NIŻ JEDEJ CECHY, to negując to pojęcie negujemy zarazem cały jego zakres i treść. Tak np. jest z pojęciem „być”, „coś” itd. Właśnie dlatego niebyt (nic) nie ma żADNEJ WSPÓLNEJ CECHY z BYTEM - z CZYMŚ. Mieszać te sprzeczne pojęcia (nic i coś), jak to czynią niektórzy filozofowie, znaczy naruszać nasze podstawowe pojęcia, uniemożliwiać wzajemne porozumienie - i nawet nie rozumieć samego siebie.

\section{V}

Kiedy pytamy, gdzie leży ta siła, która jest korzeniem, źródłem pojęcia negacji, to przede wszystkim musimy powiedzieć: tam, gdzie tkwi źródło wszystkich czystych pojęć - w REFLEKSJI. Refleksją nasz umysł wychodzi sam z siebie, żeby uświadomić sobie samego siebie - innymi słowy, żeby obEJRzeć samego siebie; wychodzi ze sfery ujęć zmysłowych (przedstawień), żeby obejrzeć byt z wyższego punktu, żeby jednym oglądem (czystym pojęciem) objąć niezliczalne przedmioty (np. pojęciem "byt" obejmujemy wszystkie istniejące rzeczy). Z tej misternej czynności naszego umysłu rodzą się najważniejsze dla nas pojęcia (jak np. pojęcia bytu, możliwości, pytania, prawdy itd.). Nie da się jednak tej misternej czynności rozpatrzeć oddzielnie, bez uwzględnienia innych sił naszej natury. Ludzka natura bowiem - to zamknięta w sobie, harmonijnie ułożona całość - tak, że jedna siła jest warunkiem innej.

Pamiętając o tym, musimy dalej pytać się o refleksję: Gdzie w naszej naturze leży warunek refleksji? Która siła w naszym umyśle w sposób naturalny (organicznie) poprzedza refleksję? Z pewnością nie wszyscy jednakowo odpowiedzą na to pytanie. Jednakże kiedy rzecz dobrze przemyślimy, to łatwo dojdziemy do przekonania, że warunek refleksji leży w wOLNEJ WOLI człowieka. Wolna wola i refleksja nawzajem się dopełniają. Refleksja w teo- 
retycznej części naszego umysłu jest tym, czym jest wolna wola w jego części praktycznej. Refleksją nasz umysł „wychodzi” sam z siebie, żeby obeJRzeć samego siebie (najbardziej wyraźnym efektem tej czynności naszegu umysłu jest nasza samoświadomość - concientia); wolną wolą nasz umysł „wychodzi” sam z siebie, żeby OPANOwAć samego siebie (najbardziej wyraźnym efektem tego procesu jest autonomia naszego umysłu). Przy pomocy refleksji jesteśmy w stanie NIE UZNAWAĆ (non concentire) wszystkiego, o czym nam donoszą zmysły (że w rzeczywistości jest tak, jak donoszą nam zmysły); za pomocą wolnej woli jesteśmy w stanie NIE GODZIĆ sIĘ na wykonanie każdego działania, które chciałaby wykonać zmysłowa część naszej natury. Ta nasza podwójna autonomia ( $\mathrm{tj}$. refleksja i wola) nierzadko sięga nawet tak daleko, że doprowadza niektóre jednostki do samozagłady: dzięki autonomii woli człowiek jest w stanie sam sobie odebrać życie (tj. zniszczyć samo źródło, z którego płynie nasze działanie); z kolei autonomią refleksji człowiek jest $\mathrm{w}$ stanie nie dać wiary całej naszej poznającej naturze (tak powstaje przesadny sceptycyzm, nihilizm w poznaniu). Gdybyśmy nie byli wyposażeni w refleksję, nasza wola nie mogłaby być wolna; i przeciwnie: bez wolnej woli refleksja byłaby pozbawiona swojej podstawy. Organiczną przewagę musimy jednak przypisać woli, a nie refleksji, ponieważ wola jest środkiem, jak gdyby sercem naszego umysłu. Stąd pierwsza inicjatywa do powstania pojęcia negacji należy do samej naszej woli. Dziecko jeszcze nie ma wyraźnego (czystego) pojęcia negacji, a już zaczyna spełniać funkcję negowania: kiedy powiesz dziecku: daj! - to odpowie ci: nie dam! - Powiesz: idź! - odpowie: nie pójdę! itd. Funkcje autonomicznej wolnej woli spontanicznie się rozwijają, a dwoma biegunami tej funkcji jest GODZENIE SIĘ i NIE GODZENIE SIĘ. To, co dalej dzieje się w woli, spontanicznie zmierza do tego, żeby znaleźć odpowiedni wyraz w myślach (w rozumie) - tak jak to, co się dzieje w naszym wnętrzu, zmierza do tego, żeby znaleźć swój wyraz na zewnątrz (w mimice, czy ruchach ciała). Świadomy wyraz tego, co się dzieje w naszej woli, kiedy odwraca się ona od jakiegoś przedmiotu czy działania, znajduje swój wyraz w pojęciu negacji. W taki oto sposób dochodzimy całkiem spontanicznie do pojęcia negacji, a rozum swymi właściwymi czynnościami to prymitywne pojęcie negacji stopniowo doskonali. 